\title{
Seed germination and seedling growth of canola treated with abiotic factors that can affect growth and development
}

Cássia Stafena, Ana Marina Pedroloa , Luciana Dallegrave Schroeder ${ }^{\mathrm{b}}$,

Vivian Eoeling Vianac, Carlos Busanelloa, Mariana Peil da Posaa,

Gilberto Omar Tomm ${ }^{\mathrm{d}}$, Antonio Costa de Oliveira ${ }^{\mathrm{a}}$, and Camila Pegoraro ${ }^{\mathrm{a}}$

aPrograma de Pós-Graduação em Agronomia, Centro de Genômica e Ftomelhoramento, Universidade Federal de Pelotas, Capão do Leão, RS, Brazil; ' 'Graduação em Biotecnologia, Universidade Federal de Pelotas, Capão do Leão, RS, Brazil; ' Programa de Pós-Graduação em Biotecnologia, Universidade

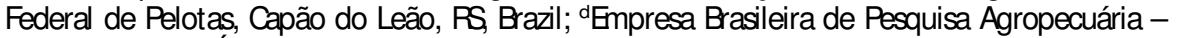

日MPRAPA Trigo, Área de Ftotecnia, Passo Fundo, RS Brazil

\section{ABSTRACT}

Canola (Brassica napus L. var. oleifera) is a source of vegetable oil. Abiotic factors may have negative impact on canola productivity. This study evaluated responses of canola hybrids under simulated flooding and drought and excess salinity. Evaluations were performed at 7 and 14 days after germination analyzing the variables percent of germinated seed, shoot length, root length, shoot dry weight, and root dry weight measured. Simulated flooding and drought and salinity detrimentally affected canola germination and initial development. Genotype expressed genetic variability for tolerance to simulated flooding and drought and salinity. The genotype "Hyola $575 \mathrm{CL}^{\prime \prime}$ was less sensitive to simulated drought and flooding and excess salinity.

\section{KEYWORDS}

Grassica napus var. oleifera; canola; drought; flooding; salinity

Rapeseed (Brassica napus L.) is a source of vegetable oil, but contains high levels of erucic acid and glucosinolates. To avoid harmful effects of rapeseed oil, plant breeders used conventional breeding techniques to reduce levels of toxic compounds producing an improved crop, i.e., canola (abbreviation for Canadian Oilseed Low Acid; B. napus L. var. oleifera), which contains low levels of erucic acid in its oil and is low glucosinolates in its meal (Loganes et al., 2016).

Canola is grown in southern Brazil as a cold season crop, with potential for expansion to central and south-eastern regions. In Brazil, canola grain is source of edible oil and has the potential for biodiesel production. Blackleg (Leptosphaeria maculans) is the main disease threat for canola in southern Brazil. Continuous use, and frequent introduction of hybrids 
Crops are frequently exposed to environmental factors that reduce growth and cause loss of productivity. Adverse environmental conditions tend to be intensified due to global climate change (Kissoudis et al., 2014). Projections indicate an increase of extreme hydrological events due to climate change, followed by an increase of frequency of flooded areas, and intensification of detrimental effects in areas already affected (Macé et al., 2016). Shortage of rainfall and prolonged dry periods in arid regions have been predicted (Gray and Brady, 2016), as well as an increased frequency of temperature fluctuations. Temperature increase contributes to incidence of drought due to higher evapotranspiration (Kissoudis et al., 2014).

When flooding occurs, there is a reduction of $\mathrm{O}_{2}$ and $\mathrm{CO}_{2}$, limitation in spreading ethylene $\left(\mathrm{C}_{2} \mathrm{H}_{4}\right)$, and electrochemical changes in the soil which result in higher concentrations of toxic elements. Flooding induces an energy crisis in plants, due to limited oxidative phosphorylation and low photosynthetic rate (Voesenek and Bailey-Serres, 2015).

Drought is characterized by reduction of water content, reduction of leaf water potential, loss of turgidity, closure of stomata, and a decrease in cell growth, which may lead to interruption of photosynthesis, disruption of metabolism, and plant death (Tekle and Alemu, 2016). In addition, drought contributes to increased soil salinization from dissolved ions due to use of prolonged irrigation (Kissoudis et al., 2014).

Salinity affects germination, vegetative growth, and reproductive development, imposes ion toxicity, osmotic imbalance, deficiency of nutrients, and oxidative imbalance, and limits absorption of water from soil. Sodium, chloride, and boron have specific toxic effects on plants, and consequently, accumulation of sodium in cell walls can lead to osmotic imbalance and cell death (Shrivastava and Kumar, 2015).

The study was undertaken to evaluate effects of simulated drought and flooding and salinity on germination and seedling growth of canola.

\section{Materials and methods}

The canola genotypes "Hyola 50," "Hyola 61," "Hyola 433," "Hyola 571CL," and "Hyola 575CL" were subjected to abiotic factors that simulated drought, flooding, and salinity, individually, before seed germination and during initial growth (up to 14 days after seeding). Experiments were conducted in a growth room at $85 \pm 5 \% \mathrm{RH}, 23 \pm 3^{\circ} \mathrm{C}$, and an $8 \mathrm{~h} \mathrm{light} / 16 \mathrm{~h}$ dark photoperiod, according to the seed testing rules (Anonymous, 2009). Seed were germinated in rolls with 2.5 sheets of germitest paper, moistened with a specific solution for each experi- 
The response of canola hybrids to flooding was evaluated by maintaining a layer of water over the germitest paper (a condition simulating poorly drained soil). A completely randomized experimental design was used, arranged in a $5 \times 2$ factorial design with five canola hybrids, without a top water layer and with top layer of water, with three replicates.

The effect of simulated drought during germination and initial growth was compared to optimal conditions for germination and growth (control). Conditions of drought were simulated using polyethylene glycol (PEG). The experiment was arranged in a completely randomized design, in a $5 \times 2$ factorial, five canola hybrids, for the control (0 MPa PEG) and simulated drought ( $-0.5 \mathrm{MPa}$ PEG), with three replicates.

To simulate effects of salinity, solutions with different $\mathrm{NaCl}$ concentration (similar to those found in soils of southern Brazil) were used. A completely randomized design was arranged in a factorial design, with five canola hybrids, and $\mathrm{NaCl}$ levels of: 0 (control), 2.5, 5.0, 7.5, or $10 \mathrm{dS} \cdot \mathrm{m}^{-1}$ converted to $0,25,50,75$, and $100 \mathrm{mM}$ (Munns and Tester, 2008), with three replicates.

Effects of simulated abiotic factors were evaluated by measuring percent germinated seed at 7 (Germ.7) and 14 (Germ.14) days, shoot length (SL), root length (RL), shoot dry weight (SDW), and root dry weight (RDW). A germination test (Germ.) was conducted according to seed testing rules (Anonymous, 2009). Seedling SL and RL were measured at 14 days after sowing (Anonymous, 2009).

SDW and RDW were determined after the shoot and root lengths were estimated. For dry weights, seedling shoots were separated from roots and each was placed inside paper bags and dried in a forced air oven set at $80^{\circ} \mathrm{C}$ for $72 \mathrm{~h}$. The samples were weighed on an analytical balance, with a precision of $0.001 \mathrm{~g}$.

Statistical analyses were performed using GENES (Cruz, 2013). Assumptions of normality of residual errors and homogeneity of variances were checked, and the data were analyzed as a factorial model. An analysis of variance was performed and if interactions were significant they were used to explain the results. If interactions were not significant, means were separated with the Tukey's test.

\section{Results and discussion}

The most adverse effects of flooding are inhibition of germination, reduction in root volume, reduced shoot growth, early leaf senescence, and plant death (Ahmed et al., 2012). In this work simulated flooding affected responses of 
Table 1. Analysis of variance for germinated seed at 7 (Germ.7) and 14 (Germ.14) days, shoot length (S)), root length (RL), shoot dry weight (SDW), and root dry weight (RDW) of canola (Brassica napus $L$ var. oleifera) genotypes under simulated flooding.

\begin{tabular}{lrrrrrrr}
\hline & \multicolumn{7}{c}{ Mean square } \\
\cline { 2 - 8 } Source & df & Germ.7 & Germ.14 & S. & RL & SDW & RDW \\
\hline Genotype & 4 & 1290.41 & 496.66 & 6.95 & 36.2 & 82.65 & 18.53 \\
Treatment & 1 & $3307.50^{*}$ & 800.33 & 0.03 & 1.63 & 803.93 & $181.79^{*}$ \\
Interaction & 4 & 247.08 & 163.33 & $2.95^{\star}$ & 7.80 & $142.87^{\star}$ & $19.19^{\star}$ \\
Eror & 20 & 118.33 & 101.66 & 0.86 & 4.56 & 21.33 & 3.90 \\
Mean & & 73.16 & 86.83 & 3.63 & 6.03 & 23.53 & 5.98 \\
CV (\%) & & 14.86 & 11.61 & 25.62 & 35.45 & 19.62 & 33.00 \\
\hline
\end{tabular}

${ }^{*}$ Sgnificant at $\mathrm{P}<0.05$.

${ }^{a} \mathrm{CV}=$ coefficient of variation; $\mathrm{df}=$ degrees of freedom.

genotype group present lower tolerance to flooding during germination, this statement is supported by Zhang et al. (2008) where reduced germination in sensitive canola genotypes flooded for 7 days have occurred.

A significant interaction between genotypes and treatment (control and simulated flooding) occurred for SL, SDW, and RDW (Table 1). In the simulated flooding, significant difference regarding SL was not detected, however, "Hyola 433" had the highest SL values in simulated flooding (Table 2). Research regarding effects of flooding on canola development are scarce; thus, model species with a known behavior under flooding can be used to explain such effects. Rice (Oryza sativa L.) presents the most well understood morphological responses to flooding. One mechanism is the quiescence strategy where SL maintenance is a typical behavior of flooding tolerant plants, suggesting that the mechanism observed in these canola genotypes is similar to the strategy used by rice when flooded (Fukao and Bailey-Serres, 2008).

Genotype affected SDW values (Table 2). Under simulated flooding, genotypes "Hyola 571CL," "Hyola 61," and "Hyola 50" were negatively

Table 2. Interaction effects of genotype and simulated flooding in canola (B. napus $L$ var. oleifera) on shoot length (SL), and shoot (SDW) and root (FDW) dry weights.

\begin{tabular}{llllllll}
\hline Genotype & Smulated flooding & \multicolumn{2}{c}{ S $(\mathrm{cm})$} & \multicolumn{2}{c}{ SDW $(\mathrm{mg})$} & \multicolumn{2}{c}{ RDW $(\mathrm{mg})$} \\
\hline Hyola 50 & No & 4.67 & $\mathrm{ab}^{\mathrm{a}}$ & 31.73 & $\mathrm{ab}$ & 8.97 & $\mathrm{ab}$ \\
& Yes & 4 & $\mathrm{ab}$ & 18.37 & $\mathrm{ad}$ & 7.7 & $\mathrm{abc}$ \\
Hyola 61 & No & 3.67 & $\mathrm{ab}$ & 26.97 & $\mathrm{abc}$ & 7.07 & $\mathrm{abcd}$ \\
& Yes & 2 & $\mathrm{~b}$ & 12 & $\mathrm{~d}$ & 1.7 & $\mathrm{~d}$ \\
Hyola 433 & No & 4.33 & $\mathrm{ab}$ & 33.97 & $\mathrm{a}$ & 11.23 & $\mathrm{a}$ \\
& Yes & 6 & $\mathrm{a}$ & 24 & $\mathrm{abc}$ & 3.15 & $\mathrm{~cd}$ \\
Hyola 571a & No & 3.33 & $\mathrm{ab}$ & 30.7 & $\mathrm{ab}$ & 8.67 & $\mathrm{abc}$ \\
& Yes & 3 & $\mathrm{~b}$ & 11.23 & $\mathrm{~d}$ & 0.01 & $\mathrm{bcd}$
\end{tabular}


affected, showing reduction in SDW. Genotypes "Hyola 433" and "Hyola 575 CL" were not affected by simulated flooding. Despite the negative effect of simulated flooding on SDW of "Hyola 50," "Hyola 61," and "Hyola 571 CL," the SL were not as above. Concerning RDW, "Hyola 433" was the only genotype to present a reduction due to simulated flooding (Table 2). "Hyola $575 \mathrm{CL}$ " was not affected either for RDW or SDW suggesting an ability to cope with simulated flooding.

Drought at planting can decrease germination rate, extend germination time, and cause biophysical changes in cell walls (Zhu et al., 2016). Drought also affects vegetative development and productivity (Farooq et al., 2009). Imbalanced osmotic conditions can affect water absorption through the seed coat by decreasing cell turgidity, an important factor for elongation, cell growth, and growth of the radicle (Nonogaki et al., 2010). The RL in genotypes and treatments was affected by simulated drought (Table 3). "Hyola 50" developed longer roots $(9.6 \mathrm{~cm})$ compared to other genotypes $(2.8-4.2 \mathrm{~cm})$. Plants that derived from seed that were not subjected to simulated drought had significantly longer roots $(6.24 \mathrm{~cm})$ than those that were subjected to simulated drought which were $3.24 \mathrm{~cm}$ in length.

Interactions between genotype and simulated drought occurred for Germ.7, Germ.14, SL, and RDW. Due to simulated drought, the Germ.7 and Germ.14 were not affected in most genotypes. However, "Hyola 571CL" had a reduction for Germ.7 and Germ.14 indicating that this genotype is negatively affected by drought during germination (Table 4) since drought decreases the germination rate, extending germination time and making biophysical changes in the cell wall (Moraes and Menezes, 2003; Zhu et al., 2016). Osmotic activity affects water absorption through the seed coat by decreasing cell turgidity, an important factor for elongation, cell growth, and the growth of radicle (Nonogaki et al., 2010). However, for most of genotypes that behavior did not occur.

Table 3. Analysis of variance for germinated seed at 7 (Germ.7) and 14 (Germ.14) days, shoot length (S)), root length (RL), shoot dry weight (SDW), and root dry weight (FDW) of canola (B. napus $L$ var. oleifera) genotypes under the drought stress.

\begin{tabular}{lccccccc}
\hline & \multicolumn{7}{c}{ Mean square } \\
\cline { 2 - 8 } Source & df & Germ.7 & Germ.14 & S & R & SDW & RDW \\
\hline Genotype & 4 & 1812.53 & 348.46 & 78.3 & $46.42^{\star}$ & 165.24 & 133.91 \\
Treatment & 1 & 3203.33 & 563.33 & 37.62 & $67.77^{\star}$ & 224.84 & 693.60 \\
Interaction & 4 & $1183.33^{*}$ & $290.33^{\star}$ & $22.24^{*}$ & 1.16 & 120.04 & $190.68^{*}$
\end{tabular}


Table 4. Interaction effects of genotype and simulated drought in canola (B. napus $L$ var. oleifera), germination at 7 (Germ.7) and 14 (Germ.14) days, on shoot length (SL) and root dry weight (RDW).

\begin{tabular}{|c|c|c|c|c|c|c|c|c|c|}
\hline \multirow{2}{*}{$\begin{array}{l}\text { Genotype } \\
\text { Hyola } 50\end{array}$} & \multirow{2}{*}{$\begin{array}{l}\text { Smulated drought } \\
\text { No }\end{array}$} & \multicolumn{2}{|c|}{ Germ.7 } & \multicolumn{2}{|c|}{ Germ.14 } & \multicolumn{2}{|c|}{$\mathrm{S}-(\mathrm{cm})$} & \multicolumn{2}{|c|}{$\mathrm{RDW}(\mathrm{mg})$} \\
\hline & & 92.67 & $a^{a}$ & 100 & $\mathrm{a}$ & 5.93 & cole & 32.27 & $a$ \\
\hline & Yes & 82 & $a b$ & 95.33 & a & 1.95 & $\mathrm{e}$ & 11.57 & $o d$ \\
\hline \multirow[t]{2}{*}{ Hyola 61} & No & 78.67 & $a b$ & 99.33 & a & 4.76 & de & 30.07 & $a b$ \\
\hline & Yes & 71.33 & $b$ & 88.67 & a & 8.37 & bod & 22.2 & $a b c$ \\
\hline \multirow[t]{2}{*}{ Hyola 433} & No & 78 & $a b$ & 86 & a & 7.4 & bod & 27.5 & $a b$ \\
\hline & Yes & 67.33 & $b$ & 91.33 & a & 12.5 & $a b$ & 16.45 & bod \\
\hline \multirow[t]{2}{*}{ Hyola 571a } & No & 86 & $a b$ & 96 & a & 5.26 & code & 24 & $a b c$ \\
\hline & Yes & 15.33 & c & 64.67 & b & 6.41 & code & 7.07 & d \\
\hline \multirow[t]{2}{*}{ Hyola 575a } & No & 98.67 & a & 100 & a & 10.4 & $\mathrm{bc}$ & 23.47 & $a b c$ \\
\hline & Yes & 94.67 & a & 98 & $\mathrm{a}$ & 15.7 & $\mathrm{a}$ & 31.93 & $\mathrm{a}$ \\
\hline
\end{tabular}

Data in the interaction analyzed with least squares means, and means separated with least significant difference.

aValues in columns followed by the same letter are not significantly different, by Tukey's test $p \leq 0.05$.

For SL, most groups were not affected by simulated drought: for "Hyola 50," treated plants had shorter shoots, and "Hyola 575 CL" treated plants had longer shoots (Table 4). Regarding RDW, "Hyola 571CL" exhibited a significant RDW reduction due to simulated drought. Genotype "Hyola 575 CL" exhibited higher RDW due to simulated drought, but did not differ from control (Table 4). Root biomass accumulation is considered an adaptation strategy to drought (Zhu et al., 2016), and this behavior occurred for "Hyola $575 \mathrm{CL}$ " indicates it can likely carry out carbon fixation in roots even under drought.

Soil salinity causes large-scale reduction of productivity (Shahbaz and Ashraf, 2013). Germination and initial stages of growth are the most susceptible to damage caused by salinity in most crops (Cuartero et al., 2006). The germination process is affected due to reduction of osmotic potential outside the seed, hindering water absorption, which is essential for that process (Soares et al., 2015). Salinity interferes in plant growth and development due to decreasing photosynthetic rate and ion exchange and nutrient absorption (Vital et al., 2008). Canola is considered moderately salt tolerant (Banaei-Asl et al., 2015), and its genotypes have different levels of tolerance to some salt concentrations (Bybordi, 2010). Genotype was affected by salinity with differences for Germ.7, Germ.14, and SL(Table 5). "Hyola 575CL" had a higher Germ.7 than did "Hyola 61," and the other genotypes were intermediate. There was no difference in Germ.14 values due to genotype (Table 6). Similar results were observed by Zamani et al. (2010) with Licord, a canola genotype, which exhibited tolerance to salinity during germination. Those observations are important to our work because the results were like those for "Uvoln $575 \mathrm{CI} "$ and indinnta that thic manntrma nracante lace coliniter cancihiliter 
Table 5. Analysis of variance for germinated seed at 7 (Germ.7) and 14 (Germ.14) days, shoot length (S), root length (R), shoot dry weight (SDW), and root dry weight (RDW) of canola (B. napus $L$ var. oleifera) genotypes under the salinity stress.

\begin{tabular}{lrrrrrrr}
\hline & \multicolumn{7}{c}{ Mean square } \\
\cline { 2 - 8 } Source & df & Germ.7 & Germ.14 & \multicolumn{1}{c}{ S. } & R & SDW & RDW \\
\hline Genotype & 4 & $1483.81^{*}$ & $697.78^{\star}$ & $38.46^{*}$ & $23.39^{*}$ & $1839.97^{\star}$ & $448.20^{*}$ \\
Treatment & 4 & 34.88 & 139.38 & 4.08 & $7.16^{*}$ & 580.23 & 129.11 \\
Interaction & 16 & 62.08 & 63.15 & 1.89 & $1.94^{*}$ & $337.96^{*}$ & $72.22^{\star}$ \\
Eror & 50 & 36.74 & 49.70 & 1.61 & 0.49 & 119.85 & 30.60 \\
Mean & & 86.18 & 88.56 & 5.30 & 4.63 & 42.48 & 19.58 \\
CV (\%) & & 7.03 & 7.96 & 23.94 & 15.22 & 25.76 & 28.24 \\
\hline
\end{tabular}

${ }^{*}$ Sgnificant at $\mathrm{P}<0.05$.

${ }^{a} \mathrm{CV}=$ coefficient of variation; $\mathrm{df}=$ degrees of freedom.

Table 6. Efect of canola (B. napus $L$ var. oleifera) genotypes on percent germination at 7 (Germ.7) or 14 (Germ.14) days and shoot (S)), over salinity level.

\begin{tabular}{lllllll}
\hline Genotype & \multicolumn{2}{c}{ Germ.7 (\%) } & \multicolumn{2}{c}{ Germ.14 (\%) } & \multicolumn{2}{c}{$\mathrm{SL}(\mathrm{cm})$} \\
\hline Hyola 50 & 94.40 & $\mathrm{ab}^{\mathrm{a}}$ & $96.13^{\mathrm{a}}$ & $\mathrm{a}$ & $4.31^{\mathrm{a}}$ & $\mathrm{b}$ \\
Hyola 61 & 72.80 & $\mathrm{c}$ & 81.06 & $\mathrm{a}$ & 4.48 & $\mathrm{~b}$ \\
Hyola 433 & 80.40 & $\mathrm{bc}$ & 83.20 & $\mathrm{a}$ & 4.83 & $\mathrm{~b}$ \\
Hyola 571a & 86.40 & abc & 87.33 & $\mathrm{a}$ & 4.75 & $\mathrm{~b}$ \\
Hyola 575a & 96.90 & $\mathrm{a}$ & 95.06 & $\mathrm{a}$ & 8.15 & $\mathrm{a}$ \\
\hline
\end{tabular}

aMeans in columns followed by the same letter are not significantly different, Tukey's test $p \leq 0.05$.

Interactions between genotype and salinity affecting RL, SDW, and RDW occurred (Table 5). The RL of genotypes treated with saline first decreased (at $25 \mathrm{mM}$ ) then increased (at $50 \mathrm{mM}$ ) and then decreased again through $100 \mathrm{mM}$. At 0 and $50 \mathrm{mM} \mathrm{NaCl}$, the RL were highest and similar. The SDW for most genotypes first decreased (at $25 \mathrm{mM}$ ) then increased (at $50 \mathrm{mM}$ ) and generally decreased to $100 \mathrm{mM}$. The exception was for "Hyola 575CL" which, for shoots, gradually decreased through $75 \mathrm{mM}$ and then increased to $100 \mathrm{mM}$. For RDW "Hyola $575 \mathrm{CL}$ " values increased at $25 \mathrm{mM}$, then decreased through $75 \mathrm{mM}$ before increasing through $100 \mathrm{mM}$ (Figure 1). In general, there was a good deal of similarity between responses for genotypes at each $\mathrm{NaCl}$ level regardless of the measured variable.

Genotype identification for higher salinity tolerance is essential since so much of the available arable land is affected by salinity. It is estimated that more than $50 \%$ of arable areas will be salinized by 2050 (Shrivastava and Kumar, 2015). The apparent salt tolerant genotypes can be used in canola breeding as a source of variability to counter the presence of salinity.

The canola genotypes responded differently when subjected to simulated flooding, drought, or salinity during germination and initial growth. That behavior demnnctrates the nrecence of oenetic variahility amono oenntvonec torxard thece 


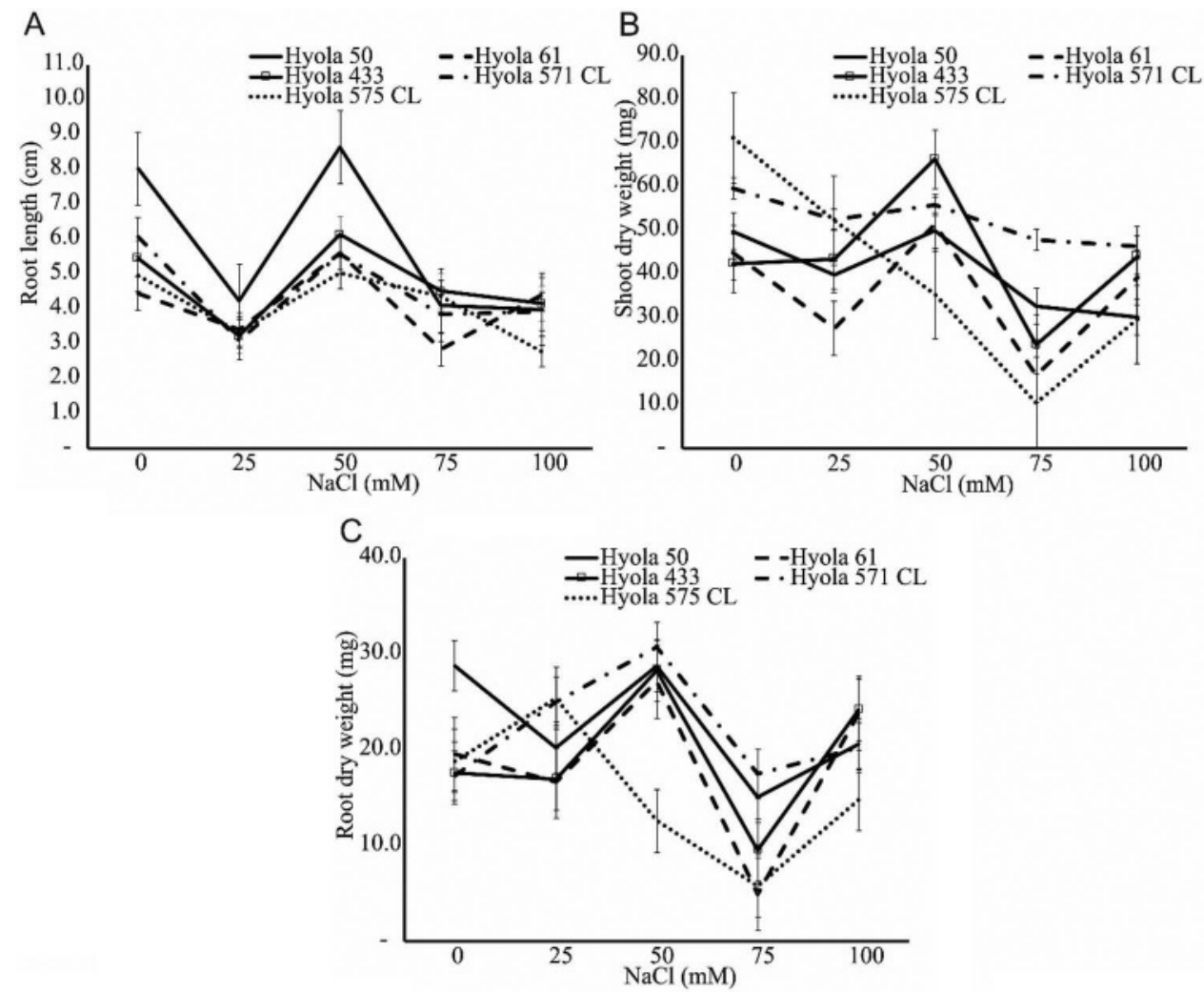

Figure 1. Effect of the interaction of saline concentrations on canola (Brassica napus $L$ var. oleifera) genotypes Hyola 50, Hyola 61, Hyola 433, Hyola 571a, and Hyola 575a for the variables: $(A)$ root length $(\mathrm{R})$, (B) shoot dry weight (SDW), and $(\mathrm{C}$ root dry weight (RDW).

development. It is necessary to identify other canola genotypes that are tolerant to the tested factors that can impair germination, growth, and development.

\section{Funding}

Research supported by Coordenação de Aperfeiçoamento de Pessoal de Nível Superior, Fundação de Amparo à Pesquisa do Estado do Rio Grande do Sul, and Conselho Nacional de Desenvolvimento Científco e Tecnológico.

\section{References}

Ahmed, F., M.Y. Rafii, M.R. Ismail, A.S. Juraimi, H.A. Rahim, R. Asfaliza, and M.A. Latif 2012. Waterlogging tolerance of crops: breeding, mechanism of tolerance, molecular approaches, and future prospects. Biomed. Res. Int. 2013:1-10. 
Bybordi, A. 2010. The influence of salt stress on seed germination, growth and yield of Canola cultivars. Not. Bot. Horti. Agrobot. Cluj-Na. 38:128-132.

Cruz, C.D. 2013. GENES - A software package for analysis in experimental statistics and quantitative genetics. Acta Sci. Agron. 35:271-276.

Cuartero, J., M.C. Bolarin, M.J. Asins, and V. Moreno. 2006. Increasing salt tolerance in the tomato. J. Exp. Bot. 57:1045-1058.

Farooq, M., A. Wahid, N. Kobayashi, D. Fujita, and S.M.A. Basra. 2009. Plant drought stress: effects, mechanisms and management. Agron. Sustain. Dev. 29:185-212.

Fukao, T., and J. Bailey-Serres. 2008. Submergence tolerance conferred by Sub1A is mediated by SLR1 and SLRL1 restriction of gibberellin responses in rice. Proc. Natl. Acad. Sci. USA 105(43):16814-16819.

Gray, S., and S.M. Brady. 2016. Plant developmental responses to climate change. Develop. Biol. 419:64-77.

Kissoudis, C., C. Wiel, R.G.F. Visser, and G. Linden. 2014. Enhancing crop resilience to combined abiotic and biotic stress through the dissection of physiological and molecular crosstalk. Front. Plant Sci. 5(207):1-20.

Loganes, C., S. Ballali, and C. Minto. 2016. Main properties of Canola oil components: A descriptive review of current knowledge. Open Agricult. J. 10:69-74.

Macé, O.G., K. Steinauer, A. Jousset, N. Eisenhauer, and S. Scheu. 2016. Flood-induced changes in soil microbial functions as modified by plant diversity. Plos One 11:e0166349.

Moraes, G.A.F., and N.L. Menezes. 2003. Soybean seed performance under different conditions of osmotic potential. Ciência Rural 33:219-226.

Munns, R., and M. Tester. 2008. Mechanisms of salinity tolerance. Annu. Rev. Plant Biol. 59:651-681.

Nonogaki, H., G.W. Bassel, and J.D. Bewley. 2010. Germination - still a mystery. Plant Sci. 179:574-581.

Shahbaz, M., and M. Ashraf. 2013. Improving salinity tolerance in cereals. Crit. Rev. Plant Sci. 32:237-249.

Shrivastava, P., and R. Kumar. 2015. Soil salinity: A serious environmental issue and plant growth promoting bacteria as one of the tools for its alleviation. Saudi J. Biol. Sci. 22:123-131.

Soares, M.M., H.C.S. Junior, M.G. Simões, D. Pazzin, and L.J. Silva. 2015. Water and salt stress in soybean seeds classifed in different sizes (Estresse hídrico e salino em sementes de soja classificadas em diferentes tamanhos). Pesquisa Agropecuária Tropical Goiânia 45:370-378.

Tekle, A.T., and M.A. Alemu. 2016. Drought tolerance mechanisms in field crops. World J. Biol. Med. Sci. 3:15-39.

Vital, S.A., R.W. Fowler, A. Virgen, D.R. Gossett, S.W. Banks, and J. Rodriguez. 2008. Opposing roles for superoxide and nitric oxide in the $\mathrm{NaCl}$ stress induce regulation of antioxidant enzyme activity in cotton callus tissue. Environ. Exp. Bot. 62:60-68.

Voesenek, L.A., and J. Bailey-Serres. 2015. Flood adaptive traits and processes: an overview. New Phytol. 206:57-73.

Zamani, Z., M.T. Nezami, D. Habibi, and M.B. Khorshidi. 2010. Effect of quantitative and qualitative performance of four canola cultivars (Brassica napus L.) to salinity conditions. Adv. Environ. Biol. 4:422-427.

Zhang, X.K., J. Chen, L. Chen, Z. Wang, and J.N. Li. 2008. Imbibition behavior and flooding 